\title{
International Constructions of Social Security and Public Health: Policy Intersections 1920-1970
}

James A. Gillespie

\section{Summary}

The problems of national health insurance played a prominent, but shifting role in the formation of global health policy. This paper uses the work of Geneva based organizations from the end of the First World War to the 1970s to explore the crossing points between health policy and social security. From its formation the League of Nations Health Organisation had an uneasy dialogue with the social insurance and security approaches adopted by the International Labour Organization and the International Social Security Association. When the social insurance concerns of the interwar year broadened into 'social security', largely led by the ILO, this debate spilled over into conflicts over the leadership of global social policy and carried over into the early years of WHO. Conflicts centred on the difficult relationship between national health insurance and the other elements of what became the welfare state. The paper identifies the difficulties of constructing a global policy space for action on health security.

Keywords: social security, International Labour Organization, global health, health insurance.

James A. Gillespie, Menzies Centre for Health Policy, School of Public Health, University of Sydney, NSW 2006 Australia (james.gillespie@sydney.edu.au) 
The historical study of the influence of global agencies, public and private, on the formation of national health policies has become a major area for study. Global health has been treated as a distinct space, with its own organizations and logic. Within International Relations, this reassessment has been led by scholars from the constructivist school, emphasising the role of that ideas have played in shaping global society. They give a major role for global organizations, such as WHO and the Red Cross, in developing and promulgating new normative orders. ${ }^{1}$ Within more conventional historiography we have seen more subtle accounts of the interaction of the national and the global, but the focus has been on intra-organizational debates, or those within networks of globally engaged professionals. ${ }^{2}$ Critiques of this approach have pointed to particular national origins of global policies or the power of hegemonic nations (the United States for much of the post-war era) to shape policy priorities. ${ }^{3}$

National action on social insurance preceded international cooperation. Medical coverage was an integral part of Bismarckian reforms of from the 1880s and Britain introduced its National Health Insurance scheme in 1911. While there was considerable interchange between European countries developing policies of social protection and health coverage, Whiteside has argued this needs to be placed in national contexts rather than as an autonomous international movement. The language of risk and social protection may have been similar, but meanings need to be located national contexts. ${ }^{4}$

The International Labour Organization played a central part in the development of international models of social security. Founded in 1919, the ILO brought together national delegations of trade unions, employers and governments, providing a unique forum for cross fertilising ideas between national delegations and functional groups. Its influence has been normative: operating almost entirely through promulgating new sets of values. ${ }^{5}$ High level Conventions, that bound their signatories to legislative action, and lower level advisory Recommendations, agreed at annual International Labour Congresses, developed stronger normative conventions around employment and labour market relations. This rule-making focused on the ILO's 'metropolitan' membership in Europe and the Americas. But the Organization made adventurous, and bitterly resisted forays into developing regulatory conventions covering the 'dependent territories' of Africa and Asia.

\footnotetext{
1 Finnemore 1996; Finnemore/Sikkink 2010; Hanrieder 2015.

2 Borowny 2009; Farley 2004.

3 Birn 2005; Gillespie 2003.

4 Whiteside 2005.

5 Finnemore/Sikkink 1998.
} 
The ILO was an early mover in the field of social protection, though with a more punctuated engagement with health. From 1927 the International Social Insurance Conference (CIMAS)/International Social Security Association worked to link national social insurance administration in a technical organization. ${ }^{6}$ It provided technical advice at annual conferences, building cooperation through sharing technical information between European social security administrations. In 1925 Harold Butler, the ILO deputy director, argued that 'health and efficiency go together'? This ILO opening to expanding social insurance to medical care was an extension of existing approaches to social insurance. Collective action rested upon a foundation individual responsibility.

The main principles of the ILO approach were based on the conventions of German and other central European social insurance systems. Social security was founded on mutualism and the contributory principle with a sharp distinction between demoralizing 'assistance' and social insurance. Social insurance was as much about the moral status of workers as about their material status, managing risk to help workers avoid falling into pauperism by pooling individual contributions. The ILO conventions on sickness (no. 18, 1925), sickness insurance (no. 24 and 25 1927-28) started to establish new international standards around income protection in case of illness.

"Social insurance organised and supervised by the State" provided a third way between individual self-help and government relief. The individual was clearly unable to save against the risks of unemployment and ill-health. At the same time, direct State provision, without individual responsibility: "involves the double danger of discouraging personal precautions against future emergencies, because the individual comes to rely entirely on state aid, and, on the other hand, of developing an entirely mechanical system of relief which will prove costly". ${ }^{8}$

This moral underpinning of social insurance carried over into a suspicion of the role of the state. Government subsidy could easily shift from the selfreliance of insurance to demoralizing assistance. Workers should have a clear entitlement to benefits, established through their individual contributions. The integrity and autonomy of the system were major priorities, with insurance funding pools administered by institutions protected from the normal workings of politics.

Healthcare was always difficult to integrate into this frame. Risks of illhealth provide an economic burden outside the scope of individual savings

6 ISSA 1986.

7 Butler 1925, 172-173.

8 ILO 1938. 
and the actuarial calculations of social insurance. ${ }^{9}$ The contributory principle - found in other areas of social insurance - was more difficult to implement in health care. Few, if any, national health insurance schemes have been self-funding, the level of risk requires state subsidy. The ILO emphasis on self-reliance, and its deep suspicion of state action made it difficult to develop a coherent health policy. A long dialogue with the League of Nations Health Organization (LNHO) explored possibilities of using social insurance as the basis for preventive health, identifying risks and intervening early. There were attempts to work with the LNHO in the late 1920s, particularly with German, Austrian and Czech social security agencies, which saw effective prevention primarily as a means to control costs, and framed in individual terms - improving the health literacy and behaviours of health fund members. The League, led by the Polish public health physician Ludwik Rajchman, expressed more interest in the possible contribution of social insurance to public health - especially the interest of insurance organizations in prevention. ${ }^{10}$

The ILO position in these debates drew on the dominant German and Czech social insurance organizations. Their officials dominated the proceedings of the ISSA's technical meetings. Social insurance models, based on firm actuarial principles, were at the basis of ILO advice. The contributory principle set restrictions on the framing of the relationships between social insurance to enable access to health care and broader principles of prevention and 'social medicine' developed by the League's Health Organization under Rajchman. Attempts at common action in the 1920s foundered over the limited control exerted by social insurance organizations over the medical services that they funded. Preventive activities were ad hoc and relied heavily on local enthusiasms of insurance officials, rather than any central principle. Despite declarations of common purpose, the goals of the two approaches remained dissimilar, and little joint action followed. Rajchman warned repeatedly that the dominant approach, represented strongly in the ILO, was the "partial or total exclusion of the public health element" from health insurance. ${ }^{11}$ Adrien Tixier, the dominant ILO thinker on social insurance, countered that the League's health officials greatly overestimated the influence of insurance organizations over medical practitioners. ${ }^{12}$

9 Freeman/Rothgang 2010.

10 Borowy 2009, 216-222, 371.

11 Ludwik Rajchman to George Newman, 24 July 1927, League of Nations Archives, Geneva, $12 \mathrm{~B} / 57687 / 57687$.

12 League of Nations Health Organization, Mixed Commission on Hygiene and Social Insurance, Sub Committee on Social Medicine, "Observations of the ILO on the First Session", 1 March 1929, League of Nations Archives, Geneva, 82/9276/7691//XI. 
By the mid-1930s cooperation between the ILO and League had shifted to different, less contentious common ground, especially around nutrition. With the collapse of liberal democratic regimes in Europe, the social insurance model was under threat, while the ILO turned its attentions to Latin America, mainly working on models of income and unemployment security.

The ILO's wartime move to Montreal shifted the frame of debate from the social insurance paradigm. The 1941 Atlantic Charter pledged a postwar world built on 'social security' - an approach explored by the British Beveridge Committee's development on models of postwar social welfare and health provision. The ILO's social insurance experts, led by Osvald Stein and Maurice Stack, attempted, with little result, to bring ILO experience into the Beveridge deliberations. Margairaz has argued the influence went the other way, part of a globalisation of a new set of norms based on the end of the old distinction between social insurance and assistance. ILO distinctions between insurance and assistance collapsed in the face of a broader 'British' concept of 'social security'. The 1938 New Zealand Social Security Act had brought the entire population under a uniform system of medical benefits funded by a universal uniform tax. This model strengthened the move towards new models of universal coverage, divorced from the European insistence on individual contributions and actuarial soundness. ${ }^{13}$

\section{ILO from social insurance to social security 1941-44}

In 1942 Stein marked this shift arguing "The idea of social security springs from the deep desire of men to free themselves from the fear of want. To realise this idea the causes of insecurity must be removed wherever possible, and the individual must be assured of that protection against the common risks of life which his own efforts do not avail to provide". ${ }^{14}$

The Philadelphia conference of the ILO in 1944 represented the high point of these post war ambitions and the shift from social insurance to 'security'. This involved a difficult set of transitions: the new emphasis on full employment as a peacetime goal was a major shift from the ILO's more passive models of insuring for unemployment.

The League of Nations Health Organization struggled to survive in the early war years and moves to build a new international health organization started by $1942 .{ }^{15}$ However, these plans were slow and limited by British

13 Margairaz 2011, 131-148.

14 ILO 1942.

15 Borowy 2009. 
suspicion of Rajchman's activism. In this vacuum the ILO moved to carve out a new space of health security. These moves faced considerable opposition from representatives of governments, especially the US and some employer representatives. The resolutions that emerged from Philadelphia were couched as advisory 'Recommendations' rather than Conventions. The Medical Care Recommendations started with a ringing declaration on the "Recognition of the essential unity of all health problems". This widened the concept of organised medical care beyond existing insurance or assistance schemes: "Illness must not only be cured - it should be prevented. Health must not only be protected - it must be improved. Care of the sick, therefore, cannot be separated from care of the healthy". The Recommendations accepted that established social insurance approaches remained an option, but preferred the models of a universal, free service, with access based on need, not by contributory status. The principle of contributory mutual help with minimal state intervention outside the state was broken in favour of a radical version of the latter. Public assistance, once a minimal and grudging safety net, was now supplanted by the principle of needs-based universal access.

This move from the passive funding of medical services through social insurance faced immediate hostility from powerful medical, government and employer interests. Edwin Witte, the veteran architect of US social security, warned that the ILO plans for health care were 'distinctly more radical than [its resolutions] on social security', and broke from established practices of funding a medical care benefit to prescribing the forms in which this would be delivered: "a program for socialized medicine, rather than social insurance". ${ }^{16}$

The ILO's engagement with health security helped shaped the focus of the new World Health Organization. WHO had tentative beginnings as an Interim Organization in 1946 and achieved full status as a United Nations Technical Agency in 1948. The British and US governments were eager to restrict the areas where WHO could interfere. However, under pressure from the French delegation section 2 (p) of the WHO Constitution (1948) included authority:

to study and report on, in co-operation with other specialized agencies where necessary, administrative and social techniques affecting public health and medical care from preventive and curative points of view, including hospital services and social security.

Like the ILO's Philadelphia Recommendations, this was a decisive shift from the insurance principle to a full blown acceptance that prevention of risk in 16 Witte 1945, 175. 
health lay as much in prevention as treatment, and that access meant taking on the main features of the organization and funding of health services.

However, lacking independent funds, WHO emphasized on programs that appealed to its funders, the communicable disease control focus that dominated its first few decades. Despite 'democratic' decision-making structures, centring on the Annual World Health Assembly, where every member had a single vote, in practice, its priorities were dominated by its main funder, the United States. Notwithstanding section 2 (p), the early WHO showed little interest in health services, their funding and policies to broaden access.

WHO's initial work in the area was reactive, responding to ILO initiatives. A major attempt to develop broad principles for the reorganisation of health systems was developed by a ILO Advisory Committee, made up of public health leaders -and led by the director of the WHO's recently established social medicine section, Milton Roemer. ${ }^{17}$ The intervention in health policy fuelled an assault on US involvement in the organization with ferocious attacks within the US on this "awesome machine bent on world domination". It was quickly suppressed by WHO under fairly open pressure from the American Medical Association. Roemer was forced to resign and WHO backed off from involvement in most issues concerning health services for many years. ${ }^{18}$

ILO interests in adding health to social security peaked in 1952 with Convention 102, an attempt to codify the new broader conception of social security. Its sweeping scope aimed to counter to the influence of the USSR (a non-ILO member) in social policy. The Convention widened the ambit of social security and included medical care provisions based on Roemer's report. These included a preference for salaried state medical services with an emphasis on preventive health. The International Labour Conference accepted Convention 102 over the opposition of all the employer representatives.

This marked a high point for ILO interests in broadening social security to include medical services. During the long reign of David Morse as director general (1948 to 1970) the ILO came under intense attack from a United States Congress hostile to involvement - and funding - of multilateral organizations outside America's direct control. Morse succeeded in maintain a reluctant US involvement, but at the price of a withdrawal from post-war social security ambitions, especially in health care.

17 Jensen 2013, 182- 184.

18 Gillespie 2002 ; Bodmer 1953.

Gesnerus 74 (2017) 


\section{Asia and the retreat from social insurance}

One area where the ILO showed considerable independence was an interest in the colonial territories of its European members. It had a long interest in conditions of forced labour in West Africa and the rights of indigenous populations, supported by its trade union members, to the frequent discomfort of government delegates at International Labour Conferences. The ILO was one of the first of the international agencies to attempt a serious engagement with the newly decolonizing nations of Asia - especially with India. The war years had seen considerable debate around improved health systems in India. In 1943 the British government appointed the Bhore Commission to report on post-war health arrangements in India. Despite a conservative membership, the Commission's report was largely the product of an advisory group whose members were familiar to interwar social medicine, including Roemer's mentor, Henry Sigerist. The Committee's 1946 report recommended an emphasis on preventive health and a national, decentralised medical service staffed by salaried doctors. ${ }^{19}$

As Indian independence became certain, the ILO picked up these themes, with a major conference in New Delhi in 1947, with its usual tripartite division of employers, government and trade unions, to discuss the application of universal principles to post-colonial realities. ${ }^{20}$

ILO officials attempted to apply the principles of universal social security developed at Philadelphia to India and similar 'non-metropolitan' countries. The general proposals were communicated to Asian countries participating before the conference and views of local officials taken into account. The response to attempts to simply apply the Philadelphia principles was not encouraging. Despite identifying numerous examples of working social insurance themes across China and India, the conference concluded:

Introduced prematurely in countries where the insured population is not properly fed, clothed and housed, where the environment is unsanitary, social security services have proved disappointing. Resources that could have been spent on promoting the general fitness of the population have been diverted to treating - naturally with only temporary success - diseases that could have been prevented. ${ }^{21}$

Instead, in words that echoed the interwar advocates of social medicine, the ILO argued for the need to start with basic prevention before building health services which would be "faced by the hopeless task of repairing damage constantly renewed, unless aided by an effective organisation of general

19 Amrith 2006.

20 ILO 1947.

21 ILO 1947, 46. 
health care aimed at preventing illness and improving the state of health". ${ }^{22}$ Lacking a national sponsor in metropolitan members and in the decolonizing world, the ILO withdrew for the next decade. ${ }^{23}$

\section{The ILO and the Cold War}

The Cold War also encouraged a retreat from broader concepts of social security. The Rockefeller Foundation also been frightened from new areas of activity in the post war years. John Grant argued to the Board that 'social medicine' with its emphasis on prevention and population level strategies, was synonymous with 'health care'. His employers quickly realized the political risks and moved to the safer waters of population policy. ${ }^{24}$

Under Morse's leadership (and with USSR joining in 1954) the ILO came under heavy pressure from the US to take the western side in the Cold War. The ILO abandoned the last traces of the Philadelphia principles - especially arguments for universal health care - as it moved towards a narrower, more 'managerial' emphasis on technical assistance. This fitted closely with the development policies emanating from Washington. Modernisation was based on the removal of hindrances to growth, replicating the historical experience of the Western developed nations. In 1950 Morse declared productivity was now the central aim of the ILO, while the proSoviet World Federation of Trade Unions held public meetings supporting the abandoned agenda. ${ }^{25}$

This was part of a broader shift within the UN system. The United States, still overwhelmingly the largest UN donor - increased its control over the spending of its contributions. Instead of flowing directly into agency budgets, UN Expanded Technical Assistance Program and Special Funds (1959) could be bid for by agencies, but within a set of priorities set by the donors. The model was largely that of Truman's Point $4-\mathrm{a}$ transposition of the Marshall Plan onto underdeveloped countries, a point reinforced as the Special Funds were directed by Paul Hoffman, formerly director of the US Economic Cooperation Administration (the Marshall Plan). ${ }^{26}$

22 ILO 1947, 78.

23 Maurel 2011.

24 Grant 1948, 381-397, Farley 2004, 275-277.

25 Aglan 2011, 236-243.

26 Jensen 2013. 


\section{Framing Health Security and Policy Space}

Rodriguez-Ocaña and Zylberman have pointed to the emergence of a distinct international health policy space in the interwar years. This was partly built on emerging levels of expertise in new global organizations: "A new type of international expertise, the LNHO went beyond the inter-governmental decision-making process to finally stand as a separate and seemingly superior space of decision and counselling". Problems that were previously seen as purely national responsibilities were now constructed as objects for international cooperation. Health security - the movement from social insurance to broader concepts of universal access. To services and prevention remained a problematic area. Action was entirely a matter for national fiscal action. The main international agencies, especially the ILO, struggled to shape an autonomous space where expertise and values could start to reshape outcomes. ${ }^{27}$

\section{Bibliography}

Amrith, Sunil S., Decolonizing International Health: India and Southeast Asia, 1930-1965 (New York 2006)

Birn, Anne-Emanuelle, Uruguay on the World Stage: How Child Health Became a World Priority", American Journal of Public Health 95/9 (2005) 1506-1517

Bodmer, Laura, "Relations between Social Security Institutions and Members of the Medical Profession", Bulletin of the ISSA VI (June-July 1953) 189-209

Borowny, I., Coming to Terms with World Health: the League of Nations Health Organisation, 1921-46 (Frankfurt a. M. 2009)

Butler, Harold B., "International Aspects of Social Insurance", in Social Insurance: its National and International Aspects and in the relation to the work of the International Labour Organization of the League of Nations. Report of a conference organized by the League of Nations Union and held at the London School of Economics November 23 $3^{\text {rd }}, 24^{\text {th }}, 25^{\text {th }}$ and $26^{\text {th }} 1925$ (London 1925)

Farley, John, To Cast Out Disease: A History of the International Health Division of the Rockefeller Foundation. 1913-1951 (New York 2004)

Finnemore, Martha, National Interests in International Society (Cornell 1996)

Finnemore, Martha/Kathryn Sikkink, "International norms dynamics and political change", International Organization 52 (1998) 887-917

Freeman, Richard/Heinz Rothgang, "Health", in: Francis G. Castles et al. (eds.) The Oxford Handbook of the Welfare State (Oxford 2010) 367-377

Gillespie, James A., "Social Medicine, Social Security and International Health, 1940-60", in: Esteban Rodriguez-Ocana (ed.), The Politics of the Healthy Life (Sheffield 2002) 225-234

27 Rodriguez-Ocaña/Zylberman 2008. 
Gillespie, James A., "International Organizations and the Problem of Child Health, 1945-1960", Dynamis 23 (2003) 115-142

Grant, John, "International Health Care", American Journal of Public Health 37 (1945) 381-397

Hanrieder, Tina, International Organization in Time: Fragmentation and Reform (Oxford 2015)

International Labour Office, Approaches to Social Security: an International Survey (Montreal 1942)

International Labour Office, Preparatory Asiatic Regional Conference of the International Labour Organization. Problems of Social Security (New Delhi 1947)

International Social Security Association, In the Service of Social Security: The History of the International Social Security Association 1927-1987 (Geneva 1986)

Jensen, Jill, "US New Deal Social Policy Experts and the ILO, 1948-1954", in: Sandrine Kott/Joelle Droux (eds.), The International Labour Organization and Beyond (London 2013) 172-189

Margairaz, Michel, "L'OIT et la sécurité du travail. Du Rapport Beveridge a la conference de Philadelphie: l'invention de la Sécurité sociale", in: Alya Aglon/ Olivier Feiertag/Dzonivar Kevonian (eds.), Humaniser le travail: régimes économiques, régimes politiques et Organisation internationale du travail (19291969) (Brussels 2011) 131-148

Maurel, Chloe, «La place des pays en voie de developpement dans la politique mondiale de l'OIT», in: Alya Aglan/Olivier Feiertag/Dzonivar Kevonian (eds.), Humaniser le travail: régimes économiques, régimes politiques et Organisation internationale du travail, 1929-1969 (Brussels 2011) 231-246

Rodriguez-Ocaña, Esteban/Patrick Zylberman, "Improving Public Health Among Crises", Dynamis 28 (2008) 19-27

Whiteside, Noel, "Comparing Welfare States: Conventions, Institutions and Political Frameworks in France and Britain since 1945", in: J.C. Barbier /M.T. Letablier (eds.), Politiques Sociales: enjeux épistémologiques et méthodologiques des comparaisons internationales (Brussels 2005) 211-229

Witte, Edwin, "1944-1945 Programs for postwar social security and medical care", Review of Economic Statistics XXVII/4 (1945) 171-187 